\title{
Erratum to: Effect of Austenite Deformation on the Microstructure Evolution and Grain Refinement Under Accelerated Cooling Conditions
}

\author{
H. ZHAO and E.J. PALMIERE
}

DOI: $10.1007 / \mathrm{s} 11661-017-4197-4$

(c) The Minerals, Metals \& Materials Society and ASM International 2017

Erratum to: METALLURGICAL AND MATERIALS TRANSACTIONS A, VOLUME 48A, JULY 2017, pp. 3389-3399 DOI $10.1007 / \mathrm{s} 11661-017-3987-z$

THE original article was supposed to publish open access per Springer Nature's compact agreement with the United Kingdom.

It is now open access and the original article was corrected accordingly.
Open access funding was provided by The University of Sheffield.

This article is distributed under the terms of the Creative Commons Attribution 4.0 International License (http://creativecommons.org/licenses/by/4.0/), which permits unrestricted use, distribution, and reproduction in any medium, provided you give appropriate credit to the original author(s) and the source, provide a link to the Creative Commons license, and indicate if changes were made.
H. ZHAO and E.J. PALMIERE are with the Department of Materials Science and Engineering, The University of Sheffield, Sir Robert Hadfield Building, Mappin Street, Sheffield S1 3JD, U.K. Contact e-mail: e.j.palmiere@sheffield.ac.uk

The online version of the original article can be found under doi: 10.1007/s11661-017-3987-z.

Article published online July 24, 2017 